\title{
Green Infrastructure and German Landscape Planning: A Comparison of Approaches
}

\author{
Catalina Vieira Mejía \\ Liubov Shirotova \\ Igor Fernando Marques de Almeida
}

\author{
Catalina Vieira Mejía, Technical University Berlin, Faculty of Planning, Building and Environment, Germany \\ (catalinavieira@gmail.com) \\ Liubov Shirotova, Technical University Berlin, Faculty of Planning, Building and Environment, Germany \\ (shirotova.lubov@gmail.com) \\ Igor Fernando Marques de Almeida, Technical University Berlin, Faculty of Planning, Building and \\ Environment, Germany (igormarquesdealmeida@gmail.com)
}

\begin{abstract}
A variety of similarities between green infrastructure and the German landscape planning can be found in comparing the approaches of the two planning instruments. Principles of green infrastructure such as multifunctionality, the multi-scale approach and connectivity show correspondences with landscape planning elements. However, some differences are apparent. The objective of this paper is to determine whether the main aims of these two frameworks overlap. It also seeks to deduce what benefits from ecosystem services could be provided by integrating the green infrastructure approach into the German landscape planning system. The results show that the green infrastructure concept is not well-known in German planning practice, although its principles are generally implemented through traditional landscape planning. Nevertheless, green infrastructure could act as a supplementary approach to current landscape planning practices by improving public acceptance and strengthening the social focus of the current landscape planning system.
\end{abstract}

Keywords: green infrastructure, German landscape planning, ecosystem services

\section{Introduction}

The Industrial Revolution has triggered a series of new technologies that have quickly transformed mankind's lifestyle and environment, resulting in big socio-economic and environmental changes around the world (Almeida, 2014). The loss of biodiversity became a major environmental challenge as a result of highly fragmented landscapes by roads and railways, intensive agriculture and urban development. Likewise, the effects of climate change threaten natural environments and urban areas. For instance, the urban heat island effect, as an anthropogenic climate modification, affects not only the local and regional climate, but also water resources, air quality, human health, biodiversity, and ecosystem functioning (Grimm et al., 2008).

Green infrastructure, a contemporary planning tool, has been increasingly used as a key element in combating these impacts. It concerns the delivery of several kinds of ecosystem services for the provision of different socio-cultural, economic and ecological benefits.

The methodological path of this paper started with an extensive literature research exploring the consolidation of the contemporary green infrastructure approach. It also concentrated on the main differences and similarities between the German landscape planning approach and the green infrastructure approach.

The materials used for the research were as follows:

- academic articles available online or in hard copy,

- books available online or in the library of the Technical University Berlin,

- bachelor and $\mathrm{PhD}$ theses available online or in hard copy, 
- relevant grey (policy, guidance and strategic) documentation available online,

- other online-sources (blog and websites).

The following sections compare some principles of green infrastructure and the German landscape planning, starting with a discussion about the definition of green infrastructure and the ambiguous literature debate about its meanings and applications (Benedict \& McMahon, 2006; Mell, 2010, 2011, 2014; Wright, 2011). The German landscape planning is then introduced in brief as the basis for further comparative analysis, to determine whether the two frameworks overlap in their main aims.

For this purpose, the three main principles of both environmental planning instruments multifunctionality, connectivity and multi-scale - are analysed. In parallel, ecosystem services are compared with landscape functions to establish the degree to which ecosystem services are explicitly addressed in open space planning. Finally, the paper examines what benefits from ecosystem services could be provided by integrating the green infrastructure approach into the German landscape planning system.

\section{What is green infrastructure?}

Green infrastructure is a relatively new research agenda. Originally, the term "green infrastructure" appeared in the United States of America in the 1990s and became the wellknown contemporary approach to landscape planning. Although, green infrastructure has applied principles adopted by predecessor approaches (e.g. garden cities), it can be considered a multifunctional approach that focuses on connectivity (Mell, 2010). This section presents the concept of green infrastructure in a European context through various definitions and their elements.

\section{Definition}

The green infrastructure concept has been applied in European policies since 2010 with the main aim to implement all European Union Biodiversity Strategy targets. The development of green infrastructure in Europe helps maintain, enhance ecosystems and their services and restore at least 15\% of degraded ecosystems (EC, 2013a). The European Commission defines green infrastructure as "a strategically planned network of natural and semi-natural areas with other environmental features designed and managed to deliver a wide range of ecosystem services. It incorporates green spaces (or blue if aquatic ecosystems are concerned) and other physical features in terrestrial (including coastal) and marine areas. On land, green infrastructure is present in rural and urban settings" (EC, 2013b: 3).

However, there are as many definitions of green infrastructure as there are people working with the concept (Mell, 2010). Benedict and McMahon (2006: 5) describe green infrastructure as "an interconnected network of green space that conserves natural ecosystem values and functions and provides associated benefits to human populations." These authors regard green infrastructure as an ecological framework needed for environmental, social and economic sustainability. They pointed out that it differs from other conservation and open space planning approaches. The main distinction is that green infrastructure is carried out in an integrated form, where conservation values and measures are considered in combination with land development, growth management and built infrastructure planning.

Mell (2010: 37) analysed several definitions and concluded that "green infrastructure is the resilient landscapes that support ecological, economic and human interests by maintaining the integrity of, and promoting landscape connectivity, whilst enhancing the quality of life, place and the environment across different landscape boundaries. In turn, the Northeast Ohio Regional Sewer District (2014: 5) defines green infrastructure in the context of a functional approach to deal with storm water, describing it as "the range of storm water control measures that use plant/soil systems, permeable pavement, or storm water harvest and reuse, to store, 
infiltration, or evapotranspiration storm water and reduce flows to the combined sewer system”.

Taking all these definitions into account, the term green infrastructure can be said to embrace all three aspects of sustainability:

- environmental, when green infrastructure acts as a network of protected land and water, controls storm water and represents natural life-support system for humans,

- social, by contributing to human health and well-being,

- the economic aspect, in its objective of sustainable economic growth.

Green infrastructure has long been widely recognised as a tool for sustainable city development, helping to identify areas where not to develop. The concept of green infrastructure has been profitably applied in many cities of the United States of America. For example, in Pittsburgh, the Allegheny Riverfront Green Boulevard project focused on improving residents' quality of life and reducing the environmental impacts of storm water runoff (Office of Economic Resilience, 2015). Likewise, green infrastructure helps the city to grow in more compact patterns (Benfield, 2011), adapting the community to the effects of climate change and natural disasters while lowering future infrastructure costs (see Greenberg \& Rogerson, 2014) and promoting community revitalisation (Office of Economic Resilience, 2015). In European cities, for instance in Germany, the green infrastructure approach with long-term goals has been implemented successfully to prevent, decelerate and reduce storm water runoff volumes, using advanced low impact development (LID) and LID-related technologies such as green roofs, swales and constructed wetlands (Nickel et al., 2014). This suggests that green infrastructure could be seen as a smart solution for today's needs (EC, 2013a).

Green infrastructure also has a vital role to play in the conservation and enhancement of biodiversity and in tackling habitat fragmentation. Depleted and isolated ecosystems resulting from highly fragmented landscapes may cease to provide valuable services. These pressures have also major consequences for the long term functioning of protected area networks. For example, Natura 2000 sites are frequently 'islands' in a landscape that do not allow dispersal and genetic exchange (BISE, 2013). Green infrastructure ensures the ecological coherence of habitats for species and essential conditions for healthy ecosystems.

This research paper is based on the European Commission green infrastructure definition, used by different European Union member states and in many studies. Furthermore, this definition is the point of departure for numerous academic articles and planning guidance as well as a useful starting point for analysis of the green infrastructure concept (Wright, 2011). Besides, some researchers explain their choice of this definition by the financial support given their projects by the European Commission.

\section{Elements of green infrastructure}

In its physical form, the green infrastructure is represented as a network of hubs, sites and links (Figure 1). These elements can be man-made or more natural/semi-natural, and also of different scales.

Hubs are the anchors of the green infrastructure network, providing habitats for biodiversity and origin for ecological processes moving to or through it (Benedict \& McMahon, 2006). Usually hubs are large protected areas, for example:

- Natura 2000 sites - network of nature protected areas in the European Union with valuable habitats for species including birds,

- natural reserves, national parks,

- working lands of conservation value, and

- recreational areas and others. 
Sites are smaller arease, which can nevertheless contribute important ecological and social values, such as protecting wildlife habitats and providing space for nature-based recreation and relaxation (Benedict \& McMahon, 2006).

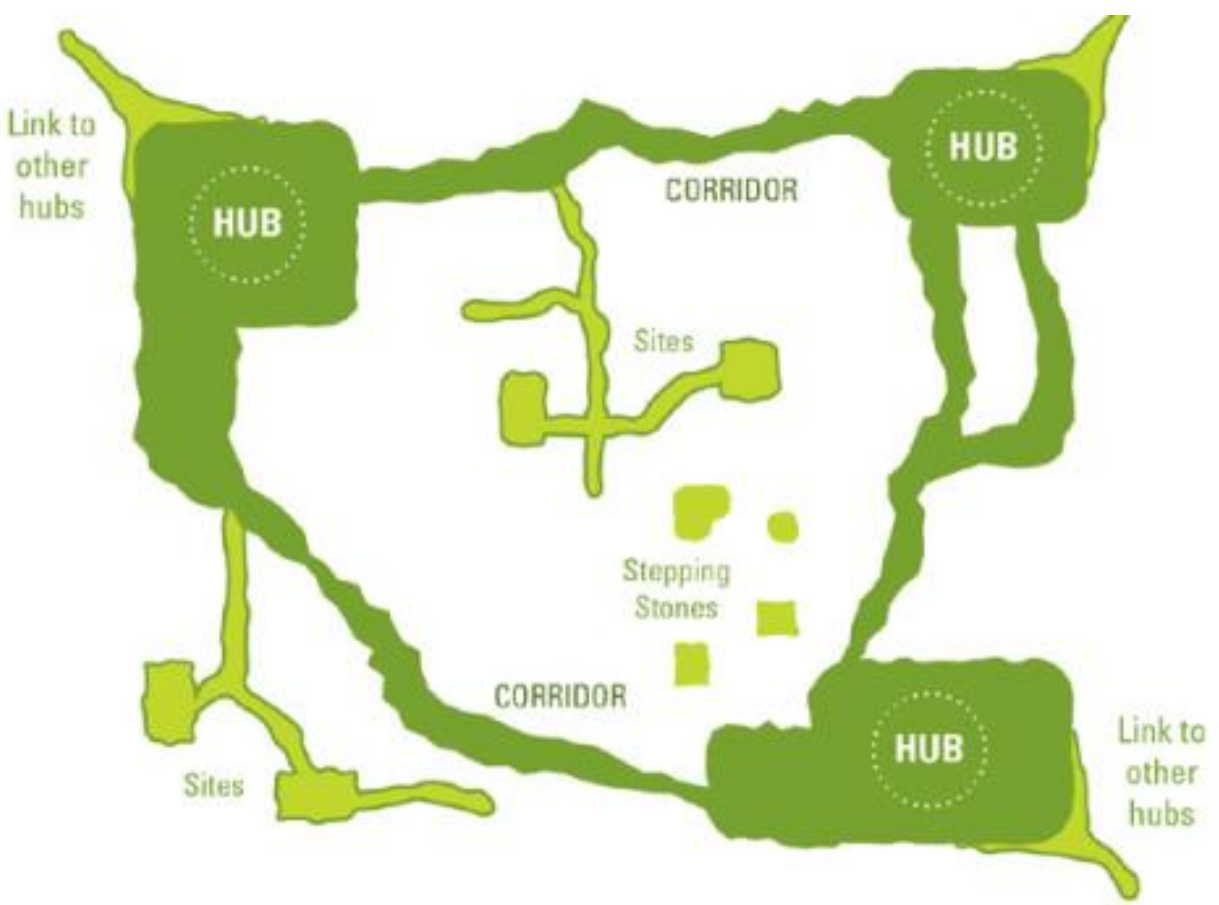

Figure 1: Green Infrastructure Network (source: Diamond Head Consulting, 2014).

Links are linear features that interconnect hubs and sites in a unified system. These connections are essential to maintain ecological processes and the health of biodiversity. Links can be classified as landscape linkages, conservation corridors, greenways and greenbelts. Long and wide landscapes linkages connect parks, reserves, or natural areas. They provide sufficient space for native plants and animals and serve for movement by people and wildlife. Conservation corridors, such as rivers, stream floodplains, forested corridors and also stepping stones, perform the function of biological canals for wildlife migration and also provide opportunities for outdoor recreation. Greenways and greenbelts are protected corridors designed to preserve native ecosystems and/or farms and ranches, and also provide recreational activities like hiking or bicycling (Benedict \& McMahon, 2006).

\section{German landscape planning}

Landscape planning has a long tradition in Germany and is a well-established planning instrument. Its development dates back to the mid-nineteenth century inspired by notions of "land enhancement" and "land beautification," strongly influenced by the earlier development of the English landscape garden (Olschowy, 1976). The movement to protect nature and the homeland appeared at the end of the nineteenth century in response to the industrialisation of the country and nature degradation (Antipov et al., 2006).

The German Federal Nature Conservation Act (Germ. Bundesnaturschutzgesetz) was passed in 1976, implementing landscape planning as a planning tool to protect and maintain the landscape and its development. Landscape planning was thus originally adopted in Germany as a planning discipline, whose principles and methods became an important and recognised aspect of nature conservation.

Landscape planning covers most aspects of environmental protection in their spatial relevance, involving gathering and summarizing information about the environment and the landscape. However, landscape planning has been developed separately from spatial planning 
(von Haaren \& Albert, 2011). Despite this division, landscape planning provides an 'ecological contribution' to comprehensive spatial planning (land use and spatial planning) and also to sectoral planning, such as traffic, agricultural and forestry planning, where consideration of the requirements of landscape plans is mandatory (Heiland, 2010). To achieve this goal, landscape planning has to be coordinated with sectoral spatial planning and decision-making. As a consequence, it is possible to resolve conflicts, improve the effectiveness of planning, enhance the ecological awareness of the public and authorities and create a planning basis for nature conservancy and recreation.

In the development of the German landscape planning, specific activities are included in the purposes of nature conservation and landscape management for the respective planning areas. To achieve such purposes, applicable measures are identified (Federal Nature Conservation Act, 2009):

- nature conservation measures, such as protection of nature, biotopes, communities and habitats of plants and animals living in the wild; establishing and protecting a biotope network and links between biotopes and the "Natura 2000" network,

- landscape management measures, such as protection, improvement of the quality of soils, water bodies, air and climate; conservation and development of the diversity, characteristics, beauty and recreational value of nature and landscape; conservation and development of open spaces in settled and unsettled areas.

In essence, German landscape planning focuses on identifying and assessing the functions and properties of the landscape. As mentioned above, it concentrates on elaborating proposals for the sustainable use and conservation of soil, water, air and climate, plants and animals, as well as the appearance and aesthetic properties of the landscape, in order to create the prerequisites for the healthy interactive functioning of these resources (Antipov et al., 2006). Under those circumstances, German landscape planning could be understood as comprehensive environmental planning based on information about ecosystem goods and services (von Haaren \& Albert, 2011).

\section{Comparison of the green infrastructure and German landscape planning approaches}

This paper examines the main three principles of green infrastructure, comparing them with the principles of landscape planning in Germany, which will allow to determine the need to integrate green infrastructure into environmental planning in Germany. The criteria for comparison taken are ecosystem services and landscape functions (multifunctionality), as well as the multi-scale and connectivity principles.

It should be noted at the outset that both green infrastructure and German landscape planning have anthropocentric approaches as key elements. However, green infrastructure focuses explicitly on human well-being, addressing the provision of benefits to humanity by nature and landscape. In contrast, the main focus of German landscape planning lies in nature protection, although it also takes an anthropocentric focus in the assessment of landscape functions and the proposal of activities to satisfy social demands (Albert et al., 2012). There is a high degree of match between the objectives of the two concepts: they seek to support environmental decisions, contribute to environmental awareness and evaluate nature and landscape (Albert et al., 2012).

For more detailed analysis, three green infrastructure principles have been selected for comparison with landscape planning: multifunctionality, multi-scale and connectivity. Although there are more principles (Mell, 2010), these three are the most often analysed in the literature referenced in this paper (Ahren, 2007; Mell, 2010; Benedict \& McMahon, 2006; Albert \& von Haaren, 2014). 


\section{Multifunctionality}

One of the crucial principles of green infrastructure is its ability to deliver several functions in the same spatial area, namely its multifunctionality. Usually, the so-called "grey" infrastructure is designed or implemented to achieve one clear objective, for instance to manage floods or provide recreational amenities for human use. In contrast, the green infrastructure goal is to interconnect different green spaces to provide a wider range of benefits and thus solve different problems (Ahren, 2007; Hansen \& Pauleit, 2014). Also, the European Commission (2013a:7) states that multifunctional green infrastructure "can promote win-win solutions or 'small loss-big gain' combinations that deliver benefits to a wide range of stakeholders." The delivery of benefits by the green infrastructure is assessed in terms of an ecosystem services approach. Before comparing the multifunctionality principle in green infrastructure and landscape planning, the different ecosystem services approaches are examined in order to define similar criteria for comparison with landscape planning.

The concept of ecosystem services was introduced by the Millennium Ecosystem Assessment (MA) (2005: 53) in the 2000s and was defined as "the benefits people obtain from ecosystems." Several years later, the Economics of Ecosystems and Biodiversity initiative (TEEB) renamed the category "supportive services" to "habitat services" and provided a new classification framework for ecosystem services (Fisher \& Christie, 2010). Finally, the European Environment Agency developed the Common International Classification of Ecosystem Services (CICES) in 2012, to standardise the definition of ecosystem services (Haines-Young \& Potschin, 2013).

Each of these classifications has its strengths and weaknesses (see Table 1). For this study, the TEEB approach is taken as the basis. It focuses on final services and avoids double counting, including habitat services as a separate category. In addition, this approach includes the monetary valuation of ecosystem services and therefore allows visualisation of the benefits for the policy decision-making process (von Haaren \& Albert, 2011; Albert et al., 2012).

Table 1: Strengths and weaknesses of ecosystem services approaches.

\begin{tabular}{lll}
\hline Approach & Strengths & Weaknesses \\
\hline MA (2005) & $\begin{array}{l}\text { Defined ecosystem services for the } \\
\text { first time. High policy impact. }\end{array}$ & $\begin{array}{l}\text { No distinction between intermediate } \\
\text { and final delivery of services. }\end{array}$
\end{tabular}

\begin{tabular}{lll} 
TEEB & Focus on final services. & No intermediate services. \\
Avoidance of double counting. & \\
& $\begin{array}{l}\text { Habitat services included as a } \\
\text { separate category. }\end{array}$ & \\
& $\begin{array}{l}\text { Considers biotic factors more } \\
\text { profoundly. }\end{array}$ & $\begin{array}{l}\text { Comprehensive approach. } \\
\text { Prioritisation needed for ecosystem } \\
\text { (2012) }\end{array}$ \\
& $\begin{array}{l}\text { Clearly distinguishing between } \\
\text { intermediate and final services. }\end{array}$ & \\
\hline
\end{tabular}

This valuation can also be useful to provide justification and set priorities for programmes, policies or actions that protect or restore ecosystems and their services (King \& Mazzotta, 2000). Furthermore, a significant number of researchers apply the TEEB classification (see Table 2) in their work. This paper refers to some of their articles.

Ecosystem services play an essential role in human life and provide the ecological, social and economic benefits for well-being and health. Ecosystems deliver important materials like food, fibre, water, timber, etc. At the same time, they regulate environmental processes and 
enhance the quality of human life and health (MA, 2005). They protect people from natural disasters such as floods, landslides, or storm water, and help them to adapt to climate change, contribute to their mental and physical health, and give them opportunities for recreation.

In the ecosystem services approache, functions and services are distinguished, which may help to gain a deeper understanding of these terms. As Hansen and Pauleit (2014: 518) note: "This distinction is important because the processes or functions of ecosystems such as soil formation may be crucial for their existence but not necessarily directly utilised by humans while a service per definition requires human beneficiaries".

Table 2: Categories of ecosystem services.

\begin{tabular}{llll}
\hline $\begin{array}{l}\text { Provisioning } \\
\text { services }\end{array}$ & $\begin{array}{l}\text { Food } \\
\text { Raw materials } \\
\text { Fresh waters } \\
\text { Medicinal Resources }\end{array}$ & $\begin{array}{l}\text { Habitat or } \\
\text { supporting } \\
\text { services }\end{array}$ & $\begin{array}{l}\text { Habitats for species } \\
\text { Maintenance of genetic } \\
\text { diversity }\end{array}$ \\
services & $\begin{array}{l}\text { Local climate and air quality } \\
\text { Carbon sequestration and } \\
\text { storage }\end{array}$ & $\begin{array}{l}\text { Cultural } \\
\text { services }\end{array}$ & $\begin{array}{l}\text { Recreation and mental } \\
\text { and physical health }\end{array}$ \\
& Moderation of extreme events & & $\begin{array}{l}\text { Tourism } \\
\text { Aesthetic appreciation } \\
\text { and inspiration for }\end{array}$ \\
& Waste-water treatment & & $\begin{array}{l}\text { culture, art and design } \\
\text { Erosion prevention and } \\
\text { maintenance of soil fertility }\end{array}$ \\
& $\begin{array}{l}\text { Pollination } \\
\text { Biological control }\end{array}$ & sense of place \\
\hline
\end{tabular}

Source: Fisher \& Christie, 2010

It is worth noting that biodiversity affects numerous ecosystem services, both indirectly and directly. For instance, by influencing primary production, nutrient cycling and water cycling, biodiversity indirectly supports the production of food, fibre and shelter (MA, 2005). Nowadays, a significant loss of biodiversity and the degradation of habitats are a result of highly fragmented landscapes and intensive land use. German roads and highways, famous worldwide for their efficiency, can be mentioned as an example of fragmented elements of the landscape (Bruns et al., 2000).

As an answer to these problems, the European Commission set the target to halt biodiversity loss in Europe by 2020 and promoted the Green Infrastructure Strategy. This strategy addresses the main drivers of biodiversity loss (EC, 2013a). Green infrastructure serves as a safeguard for ecosystem services provision and increases the value of the goods and services that ecosystems deliver (Lafortezza et al., 2013).

In German landscape planning, the term 'ecosystem services' is not used, but so-called 'landscape functions' could be interpreted as a 'proxy' for the supply of ecosystem services (Albert \& von Haaren, 2014).

A landscape function is defined as "the capacity of a landscape and its subspaces to sustainably fulfil basic, lasting and socially legitimised material or immaterial human demands" (von Haaren \& Albert, 2011). In other words, a landscape function is the ability of a landscape to provide services to satisfy human needs.

Landscape functions overlap with ecosystem services, although they are not always identical. In contrast to the valuation of ecosystem services from an economic perspective, landscape planning does not assess the monetary value of landscape functions. For example, the natural yield potential of a landscape is recognised, but not the achievable levels of food production (von Haaren \& Albert, 2011). 
According to the Federal Nature Conservation Act, a variety of landscape functions should be evaluated regarding their current state and future performance (e.g. biodiversity function, natural yield function, water resources function, water pollution protection function, retention function, climate functions, landscape experience function, multifunctional areas) (Federal Nature Conservation Act, 2009). In view of the above considerations, it can be concluded that the two concepts (ecosystem services and landscape functions) are comparable and amenable to more detailed analysis.

Although ecosystem services have been described in detail, the mechanism of their integration into the planning system is not yet clear. Albert et al. (2012) accordingly compare the concepts of ecosystem services and landscape planning. They use the TEEB ecosystem services classification. For comparison purposes, landscape functions under the applicable legislation (German Federal Nature Conservation Act) are examined. However, these considerations are theoretical and it is therefore necessary to include information from practitioners for more far-reaching assessment.

It should be noted with regard to the analysis by Albert et al. that through the assessment and enhancement of landscape functions, landscape planning covers most of the ecosystem services covered by green infrastructure. Specific weaknesses or shortcomings in ecosystem services provision were found:

- Medicinal resources: they are not included in landscape planning analysis

- Availability of wind, sun and water to produce energy: service not considered by ecosystem services approach, but by landscape planning as a landscape function

- Wastewater treatment, pollination and biological control: they are associated with some landscape functions. This match is formulated from legislation, but in practice, landscape planning does not deal with them (Albert et al., 2012)

- Tourism: experience and perception of the landscape and the recreational value of the countryside are included in landscape planning, but only through the consideration of landscape conditions and touristic infrastructure

- Aesthetic appreciation and inspiration for culture, art and design: this is partly included. Only benefits for artistic inspiration are not addressed by landscape planning.

As an additional point, it is recognised that ecosystem service approaches improve communication of the ecosystem and biodiversity benefits provided to people, as well as the impacts that different planning activities could have on this provision (Albert et al., 2014). These ecosystem services approaches are therefore well accepted in the political context and considered an aid to decision-making.

\section{Multi-scale approach}

A multi-scale approach is a key idea of landscape ecology that comprises the analysis, assessment and planning of both ecological processes (e.g. water cycle, energy flow etc.) and landscape pattern at different levels or scales and their interaction (Ahern, 2007). Landscape pattern contains three main components (Riitters et al., 1995):

- Landscape composition, represented on the landscape by the variety and relative abundance of patch types

- Landscape configuration, associated with the spatial arrangement, position, orientation or shape complexity of patches on the landscape

- Landscape connectivity, linking landscape patches.

These components bring more clarity about the importance of multi-scale analysis. The size of areas and type of green space (from green roofs and city parks to large protected areas like Natura 2000) differ greatly, as do locations and interconnections. Taking a single-scale approach in addressing a plan or programme consequently proves to be rather difficult. 
Landscape planning in Germany takes place at four different scales, generally according to the level of administrative areas: state, region/district, municipality and part of the municipal area (von Haaren et al., 2008). The Federal Nature Conservation Act, requires landscape planning to be carried out on two or three levels, depending on the state (Federal Nature Conservation Act, 2009):

- Landscape programme: It is elaborated as a functional nature conservation concept to lay down nature conservation and landscape maintenance requirements and measures for the states. It also sets programmatic objectives and guidelines for the nature conservation policy of a state

- Landscape structure (master) plan: This describes the requirements and measures for individual regions (districts) in more concrete terms. Areas that require conservation are shown, as well as areas for the regional biotope network

- Landscape plan: It sets local requirements and measures at the municipality level (with the exception of the city states Berlin, Bremen and Hamburg, as well as the states North Rhine-Westphalia and Thuringia) and includes the function of more detailed environmental assessment and urban green space tasks

- Open-space structure plan: The plan is drawn up for parts of municipal areas to provide greater details for the landscape plan (not in all states).

Evidently, plans or programmes at various levels specify nature conservation and landscape management goals, requirements and measures for the corresponding level. In certain cases, some conservation requirements or management activities could be omitted at a certain level if they are developed in detail at a higher level.

Even though the German landscape planning considers four different scales, there are no responsible authorities for planning at the national level, due to the designation of nature conservation responsibility to the states. Thus, some difficulties can appear in the management of large areas with cross-borders or to address national strategies such as Biodiversity Strategy or Natura 2000.

Likewise, green infrastructure connects a variety of green spaces at different scales: from national, state and regional to community and parcel scales (Benedict \& McMahon, 2006; Hansen \& Pauleit, 2014). Hence, landscape planning, as well as green infrastructure, operates at multiple scales in tandem, which leads to their successful implementation on practice. Some projects in Germany are named as green infrastructure projects and developed at different levels. Some of them are also objects of German landscape planning, such as the case of the Natura 2000 network.

\section{Connectivity}

The final principle to consider in comparing green infrastructure and landscape planning is connectivity. Connectivity in the green infrastructure approach is the interlinkage of green spaces - not just physically but also functionally. In this way, it facilitates the flow of energy, materials, nutrients, species, and people across a landscape, which can improve the provision of ecosystem services (Ahern, 2007). For instance, an individual tree as a green element can have a higher value if it forms part of a larger habitat or ecosystem. In effect, the provision of ecosystem services (as habitats for species) is enhanced and a broader variety of species can take advantage of it.

Examples of green infrastructure elements that provide connectivity are wildlife overpasses. They increase benefits for biodiversity due to their function as ecological corridors that facilitate the movement of wildlife through fragmented landscapes. In urban areas, connected green elements provide not only ecological benefits but also social ones. They create a greater sense of community, provide incentives for voluntary action, and help to combat social exclusion and isolation (EC, 2013a). 
The principle of connectivity also comes to bear in German landscape planning. Connectivity is addressed through habitats networks, also called biotope networks (Germ. Biotopeverbund), and multifunctional greenways (Germ. Grünzüge) (von Haaren et al., 2008).

The habitat network is one of the objectives of the German Federal Nature Conservation Act for safeguarding, in the long term, native animal and plant species, as well as their ecological interrelations (von Haaren et al., 2008). The act requires habitat networks to cover a minimum of $10 \%$ of the total land area of the German states. The purpose of habitat networks is nature conservation; they were first established to counteract fragmentation by creating habitat corridors and stepping stones to prevent local extinction (von Haaren \& Reich, 2006). Natura 2000 areas can be integrated in the national habitat network.

Furthermore, habitat networks should be considered at different levels to include elements of different sizes and different targeted species such as Natura 2000. In practice, however, habitat networks are mainly included in local and regional landscape planning (von Haaren \& Reich, 2006). Some categories of habitat network approaches are:

- Species-oriented habitat networks: They seek to protect selected species by preserving core areas with the development of corridors and stepping stones

- Multifunctional habitat networks: This is a broader multifunctional approach, not focusing on specific species. Multifunctional habitat networks integrate the same elements as species-oriented habitat networks, but aim to reconnect remnant habitats with areas of greater importance for nature conservation

- Measures to reduce barrier effects: Individual elements that avoid or mitigate the impacts caused by man-made barriers (e.g. wildlife overpasses or fish ladders).

The second instrument used by German landscape planning to address connectivity is the multifunctional greenway. Originally, greenways were implemented to prevent urban sprawl, to separate settlements, to provide recreational opportunities, and to improve air quality in industrialised urban areas (von Haaren \& Reich, 2006).

Currently, multifunctional greenways are used as an official planning category, mainly implemented at the regional level. Greenways usually promote recreation, air regeneration, habitat and species conservation, agriculture and forestry. These greenways also resolve ecological problems in areas of dynamic urbanisation or industrialised and densely populated areas.

To conclude, Germany uses two different approaches to connect green areas, instead of one, multifunctional concept. The approach to be applied depends on the main objectives:

- multifunctional greenways systems for recreational and climatic functions or

- species-oriented habitat networks for species and habitat conservation as the principal focus.

In both cases, some effects and benefits are addressed only in a general way, without considering them as an objective (e.g. the positive effects of recreation and climate control by species-oriented habitat networks) (von Haaren \& Reich, 2006).

By bringing together the objectives of habitat networks and multifunctional greenways, it is fair to say that the principle of connectivity is taken into consideration in German landscape planning and in green infrastructure. Nevertheless, the implementation of one multifunctional network approach, which concentrates on providing all ecosystem services, as does a green infrastructure strategy, could produce more effective results.

\section{Conclusion}

The survey has shown that the green infrastructure concept is not well-known in German planning practice. At first glance, green infrastructure encompasses all the objectives of the traditional German landscape planning system and there is thus no need to introduce the concept in Germany. However, comparative analysis of green infrastructure and landscape 
planning principles shows that green infrastructure could act as a supplementary approach to current landscape planning practices.

First of all, green infrastructure can ensure the general framework for a habitat network at the national and transnational levels. Since German landscape planning gives the responsibility to the states to develop their habitat network strategy, a united coherent framework at the national level could enhance the implementation of nature conservation targets.

There is no common green infrastructure framework among European countries, although several transnational green infrastructure projects have been developed with the participation of Germany. The introduction of this common green infrastructure framework could help to achieve European Commission targets (e.g. Biodiversity Strategy) through joint efforts between countries and the sharing of knowledge. The common framework could also facilitate the policy-making and the implementation of measures, such as incentives and support for the implementation of a green infrastructure strategy.

Secondly, the connection between the green infrastructure concept and the ecosystem services approach permits a clear understanding of the delivery of multiple benefits for human well-being, and therefore it makes easier pinpoint priorities. Currently, German landscape planning operates with the analysis of landscape functions, a methodological approach considered similar to the ecosystem services method.

Nevertheless, landscape functions perceive ecosystems as natural assets and not as benefits for human well-being. It also does not take their monetary value into account. Although from the legislative perspective landscape planning addresses most ecosystem services, in practice some are omitted. For this reason, the integration of a unified and systematic approach in German open space planning, such as the ecosystem services approach, could improve the comprehension of different analyses and the decision-making process.

Finally, for communicational purposes, green infrastructure is perceived as a potential instrument to complement German landscape planning. In landscape planning, only legitimised (usually elected) representatives make final planning decisions. The integration of green infrastructure into communication strategy could help to build community awareness and support for projects and initiatives (see Cerar, 2014). Moreover, green infrastructure endeavours to facilitate the decision-making process by generating a clear comprehension of the possible ecosystem benefits and their monetary valuation. Consequently, landscape planning could be improved by understanding and collaboration among different stakeholders.

Despite the many positive aspects, the introduction of the new term, green infrastructure, may be confusing for German practitioners who have been operating with well-established landscape planning for many years. However, this paper suggests that German landscape planning could integrate some aspects of green infrastructure. The combination of good practices of the ecosystem services approach with landscape planning could bring fresh air into traditional methods, as well as improve public acceptance. As well, the strengthening of the focus on social aspects can improve the current landscape planning system, where nature conservation has priority.

\section{Acknowledgments}

We wish to thank Dr. Dorothea Hokema, of the Department of Landscape Planning and Landscape Development, of the Technical University Berlin, for her invaluable support and advice throughout the entire research. Without her this research would not have been possible. 


\section{References}

Ahern, J. (2007) Green infrastructure for cities: The spatial dimension. In: Novotny, V., \& Brown, P. (eds.) Cities of the future, towards integrated sustainable water and landscape management, pp. 267-283. London, IWA Publishing.

Albert, C., von Haaren, C. \& Galler, C. (2012) Ecosystem services - Old Wine in New Bottles or an Incentive for German Landscape Planning? Naturschutz und Landschaftsplanung, 44 (5), pp. 142-148.

Albert, C., Aronson, J., Fürst, C. \& Opdam, P. (2014) Integrating ecosystem services in landscape planning: requirements, approaches, and impacts. Landscape Ecol. 29, pp. 1277-1285. DOI: 10.1007/s10980-014-0085-0

Albert, C. \& von Haaren, C. (2014) Implications of applying the green infrastructure concept in landscape planning for ecosystem services in peri-urban areas: an expert survey and case study. Available at: http://dx.doi.org/10.1080/02697459.2014.973683 (accessed 29 Jan. 2015).

Almeida, I. F. M. (2014) Industrial development and urban space production: the case of the Torre Factory. Bachelor thesis. Recife, Federal University of Pernambuco.

Antipov, A. N., Kravchenko, V.V., Semenov, Yu.M., Drozdov, A.V., Winkelbrandt, A., Milken, W., et al. (2006) Landscape planning, tools and experience in implementation. Irkutsk, V.B. Sochava Institute of Geography SB RAS Publishers.

Benedict, M. \& McMahon, E. (2006) Green Infrastructure: smart conservation for 21th century. Washington, D.C., Prawl Watch Clearinghouse.

Benfield, K. (2011) How green infrastructure is making cities more sustainable and hospitable. Available at: http://switchboard.nrdc.org (accessed 20 Jul. 2015).

[BISE] Biodiversity Information System for Europe (2013) Green Infrastructure. European Union and European Environmental Agency. Available at: http://biodiversity.europa.eu (accessed 14 Jul. 2015).

Bruns, D., Ipsen, D. \& Bohnet, I. (2000) Landscape dynamics in Germany. Landscape and Urban Planning, 47(3-4), pp. 143-158.

Cerar, A. (2014) From reaction to initiative: Potentials of contributive participation. Urbani izziv, 25(1), pp. 93-106. DOI: 10.5379/urbani-izziv-en-2014-25-01-002

Diamond head consulting (2014) Biodiversity conservation strategy. City of Surrey, BCS.

[EC] European Commission (2013a) Building a Green Infrastructure for Europe.

Luxembourg, Publications Office of the European Union.

[EC] European Commission (2013b) Green Infrastructure (GI) - Enhancing Europe's Natural Capital. Communication from the commission to the European parliament, the council, the European economic and social committee and the committee of the regions. Available at: http://ec.europa.eu/environment/nature/ecosystems/ (accessed 20 Jun. 2015).

Federal Nature Conservation Act 2009. Federal Law Gazette I, no. 2542. Berlin.

Fisher, B. \& Christie, M. (2010) Integrating the ecological and economic dimensions in biodiversity and ecosystem service valuation. In: Kumar, P. (eds.) The Economics of Ecosystems and Biodiversity (TEEB), The Ecological and Economic Foundations, pp. 140. London and Washington, Earthscan.

Greenberg, D.A. \& Rogerson, J.M. (2014) The greening of industrial property developments in South Africa. Urbani izziv, 25(supplement), pp.122-133. DOI: 10.5379/urbani-izziven-2014-25-supplement-009

Grimm, N.B., Faeth S.H., Golubiewski N.E., Redman C.L., et al. (2008) Global change and the ecology of cities. Science, 319(5864), pp. 756-760. DOI: 10.1126/science.1150195

Haines-Young, R. \& Potschin, M. (2013) Common International Classification of Ecosystem Services (CICES): Consultation on Version 4, August-December 2012. Report to the 
European Environment Agency. Available at: http://cices.eu/resources/ (accessed 6 Jun. 2015).

Hansen, R. \& Pauleit, S. (2014) From Multifunctionality to Multiple Ecosystem Services? A Conceptual Framework for Multifunctionality in Green Infrastructure Planning for Urban Areas. AMBIO, 43, pp. 516-529. DOI: 10.1007/s13280-014-0510-2

Heiland, S. (2010) Landschaftsplanung. In: Henckel, D. et al., (Hrsg.) Planen - Bauen Umwelt. Ein Handbuch. pp. 294-300. Wiesbaden.

King, M. \& Mazzotta, M. (2000) Ecosystem evaluation, Glossary. Available at: http://www.ecosystemvaluation.org/glossary.htm (accessed 21 Jul. 2015).

Lafortezza, R., Davies, C., Sanesi, G., Konijnendijk, C.C. (2013) Green Infrastructure as a tool to support spatial planning in European urban regions. iForest-Biogeosciences and Forestry, 6, pp. 102-108. DOI: 10.3832/ifor0723-00

[MA] Millennium Ecosystem Assessment (2005) Ecosystems and Human Well-being. A framework for assessment. Washington, Island Press.

Mell, I. C. (2010) Green infrastructure: concepts, perceptions and its use in spatial planning. $\mathrm{PhD}$ Thesis. United Kingdom, Newcastle University.

Mell, I. C. (2011) Green Infrastructure planning: A contemporary approach for innovative interventions in urban landscape management. Journal of biourbanism, 1(1). pp. 29-39.

Mell, I. C. (2014) Aligning fragmented planning structures through a green infrastructure approach to urban development in the UK and USA. Urban Forestry \& Urban Greening, 13, pp. 612-620. DOI: 10.1016/j.ufug.2014.07.007

Nickel, D., Schoenfelder, W., Medearis, D., Dolowitz, D.P., Keeley, M., Shuster, W (2014) German experience in managing storm water with green infrastructure, Journal of Environmental Planning and Management, 57 (3), pp. 403-423. DOI: 10.1080/09640568.2012.748652

Northeast Ohio Regional Sewer District (2014) Green infrastructure definition and strategy, Project Clean Lake. Available at: http://geaugaswcd.com/ (accessed 14 Jul. 2015).

Office of Economic Resilience (2015) Green infrastructure and sustainable community initiative. Available at: http://portal.hud.gov/ (accessed 14 Jul. 2015).

Olschowy, G. (1976) The development of landscape planning in Germany. Landscape Planning, 3, pp. 391-411. DOI: 10.1016/0304-3924(76)90083-6

Riitters, K.H., O’Neill, R.V., Hunsaker, C.T., Wickham, J.D., et al. (1995) A factor analysis of landscape pattern and structure metrics. Landscape Ecology, 10, pp. 23-39. DOI: 10.1007/BF00158551

Von Haaren, C. \& Reich, M. (2006) The German way to greenways and habitat networks. Landscape and Urban Planning, 76 (1-4), pp. 7-22. DOI: 10.1016/j.landurbplan.2004.09.041

Von Haaren, C. et al. (2008) Landscape planning, the basis of sustainable landscape development. Leipzig, Federal Agency for Nature Conservation.

Von Haaren, C. \& Albert, C. (2011) Integrating ecosystem services and environmental planning: limitations and synergies. International Journal of Biodiversity Science, Ecosystem Services \& Management, 7 (3), pp. 150-167. DOI: $10.1080 / 21513732.2011 .616534$

Wright, H. (2011) Understanding green infrastructure: the development of a contested concept in England. Local Environment: The International Journal of Justice and Sustainability, 16 (10), pp. 1003-1019. DOI: 10.1080/13549839.2011.631993 